\title{
Visualizing Mathematics: The Use of Block Models for Strategic Problem Solving
}

\section{Julius R. Garzon ${ }^{1}$, Leomarich F Casinillo²}

${ }^{1}$ Master Teacher I, Ibarra National High School, SDO-Maasin City, Philippines

${ }^{2}$ Visayas State University, Visca, Baybay City, Leyte, Philippines

A R T I C L E I N F O

Article history:

Received 02 December 2020

Received in revised

Form 06 January 2021

Accepted 30 January 2021

Available online 06

February 2021

Keywords:

Block Modeling,

Problem-Solving Ability

\section{A B S T R A C T}

The ability to visually manipulate problem quantities is often the key to understand effectively the concept towards proper solution process. Modeling blocks in a problem text is a visual mathematical technique that utilizes bar models to express relationship between known and unknown numerical elements. Facing a dismal performance among students entering high school with poor basic problem-solving skills, this study is an attempt to investigate how block model approach potentially reinforce students' heuristic skills (analytical \& procedural) in solving mathematical problems. Two classes of grade 7 students in Ibarra National High School, Maasin City, Philippines were used as participants which is assigned into groups, that is, control and experimental groups. Control group was taught using conventional method while the experimental group was taught using the concept of block model. Using quasiexperimental design, the data analysis revealed significant increase in scores and significant mean difference in problem-solving skills between groups who used and did not use block model method. In conclusion, utilization of block models gives high potential in developing strategic problem-solving ability of learners. Hence, this approach should be incorporated by mathematics teachers in their teaching strategies.

\section{Introduction}

The changing landscape of Philippine K-12 education system has required teachers' adaptability, creativity and innovativeness in molding learners to be critical thinkers and good problem solvers (Casinillo \& Aure, 2020). Teaching strategies of a mathematics teachers are the key to develop students' problem solving skills (Leonard, 2018). Modeling a process to visualize problem content is necessary in order to lead students to apply concept into the solution process correctly (Kaur, 2019). This leads to the concept called Block Modeling. This study claims that teaching students the use of Block Models as a visual approach in solving mathematical problems through explicit instruction develops their problem-solving ability.

The development of successful problem-solving skills is a key part of mathematics learning and it is a primary concern of teachers to students. Visualizing a problem often is the key to helping students understand the problem and develop a solution (Emeny, 2014; Kenan, 2018; Krawec, 2014). Block Model method gained popularity in Singapore as it empowers learners to solve mathematics problems that were traditionally set only at higher levels (Fong, 1993; Fong, 1999a; Fong, 1999b; Ng \& Lim, 2001). Students learn to represent simple and multi-step word problems by drawing bars to indicate how the known elements of the problem relate to one another, and then place one or more question marks to indicate what they need to find out (Hoven \& Garelick, 2007). Seemingly, a positive learning experiences in mathematical problem solving leads to a good academic level of achievement (Casinillo \& Casinillo, 2020; Casinillo et al., 2020a). Mathematical models help students gain concrete experiences which are prerequisites for understanding abstract symbols of mathematics and their manipulation (Kho, 1982). The model method provides many opportunities to use heuristics such as "Draw a diagram", "Use a model", or "Use visualization" (Cheong, 2002). Visual representation in mathematics involves creating and forming models that reflect mathematical information (Garderen \& Montague, 2003). It is an important skill because higher-level math and science courses increasingly draw on visualization and spatial reasoning skills to solve problems (Zhang, Ding, Stegall, \& Mo, 2012). Block modeling enables the students to make abstract problems more concrete and facilitate algebraic reasoning in students of all ages (Hong, et al., 2009; Petti, 2014). 
Filipino students have performed way below par in national achievement tests (NAT) in the field of science and mathematics (Suarez \& Casinillo, 2020). Perhaps, Filipino students performs below the levels of most students from other nations especially in problem solving (Gonzales et al., 2003). Meanwhile, problem-solving performance of learners remains an issue in mathematics program in the Philippines, especially in Ibarra National High School, Maasin City. Although literature explained visual approaches and its utility in success of mathematics, most teachers tone down its practices in classroom setting as far as problem-solving skill acquisition is concerned (Rozencwajg, 1991; Sonico, 2012). There are very few studies that have explored about its effectiveness and contributory role in maximizing problem-solving ability particularly Philippine setting. This in turn provides a gap in literature in the area of empirical analysis of the effect of block modeling on problem solving skills through collaboration in explicit instructional approach.

Therefore, this study is conceived to prove the assumption. In general, this study attempts to examine the effectiveness explicit block model approach in improving problem solving skills of the grade 7 students. Specifically, it seeks answers to the following objectives: (1) to determine the level of problemsolving skill of respondents before and after applying explicit block modeling in solving mathematical problems; (2) to determine if there is a significant improvement in problem-solving skills among students; and (3) to determine if there is a significant difference between students who used and did not use block modeling technique as visual approach to problem-solving. This study also aims to suggest some policy inputs to improve the mathematics education in the Philippines.

\section{Methods}

This quantitative research utilized a quasi-experimental design based on the current study, involving two equivalent independent groups engaged in pretest-posttest (Suarez \& Casinillo, 2020; Yunzal \& Casinillo, 2020). Some descriptive statistics was used to describe the data collected and in determining the significant difference or the effectiveness of the intervention, T-test was used as inferential statistics method. Before the conduct of the study, the permission of the School Head of Ibarra National High School, 2nd District of Schools Division of Maasin City was requested through a formal letter. After that, the permission of two mathematics teachers was also asked to collaborate in the study. The study was carried out in 18 days to two intact (homogeneous) classes with 24 Grade 7 students each. Students of Teacher A was considered the control group and students of Teacher B was considered as experimental group. It started around 3rd week of June towards mid-July of last School Year 2019-2020. Explicit instruction with collaborative problem-solving activities using block models was employed for experimental group while conventional 4-step process was for control group. To ensure variability of groups, students' final grade in Grade 6 Mathematics of the previous year were considered. Attendance was completed while internal validity was kept without intervention of absences. Given the 5-item worded problem test instrument on basic number sense, duly validated and pilot-tested, problem-solving skills were assessed via 4-point scaled rubric (Punzalan \& Buenaflor, 2017).

In this study, no sensitive information was gathered, in other words, the study is pure academic in nature. Hence, students' parents' consent was not needed to ask. To ensure accuracy and precision of data analysis, proper statistical treatment such as mean and standard deviation, levene's test, paired t-test and independent two-sample t-test were employed with the facility of SPSS software version 20.

\section{Result and Discussion}

\section{Results}

Table 1 reflects students' level of problem-solving performance before and after the intervention. It presents the descriptive statistics for control and experimental groups in terms of pretest and posttest scores.

Table 1. Level of Problem-solving Skills of Learners

\begin{tabular}{lcccc}
\hline & \multicolumn{2}{c}{ Control Group } & \multicolumn{2}{c}{ Experimental Group } \\
\cline { 2 - 5 } & Pretest & Posttest & Pretest & Posttest \\
\hline Mean & 6.25 & 8.37 & 8.06 & 14.90 \\
Standard Deviation & 1.80 & 1.66 & 1.45 & 2.44 \\
Description & Developing & Developing & Developing & Proficient \\
\hline
\end{tabular}

Legend: Beginning (1-4); Developing (5-8); Approaching Proficiency (9-12); Proficient (13-16); Advanced $(17-20)$ 
Table 2 illustrates the results of the test measuring the significance of increase in the mean scores from pretest to posttest of students exposed to the block model. Data were derived using Paired t-test at $1 \%$ level of significance.

Table 2. Significance of Increase in the Mean Scores

\begin{tabular}{|c|c|c|c|c|c|c|}
\hline \multicolumn{6}{|c|}{ Paired Differences } & \multirow[b]{2}{*}{ Interpretation } \\
\hline Test Compared & Mean & $\begin{array}{c}\text { Standard } \\
\text { Deviation }\end{array}$ & $\mathbf{t}$ & df & p-value & \\
\hline $\begin{array}{l}\text { Pretest } \\
\text { Experimental Group } \\
\text { to Posttest } \\
\text { Experimental Group }\end{array}$ & 6.84 & 1.28 & $24.31 *$ & 23 & $<0.001$ & $\begin{array}{l}\text { Significantly } \\
\text { Different }\end{array}$ \\
\hline
\end{tabular}

*Increase in mean values is significant at p-value $<0.01$

Table 3 reveals the computed values of the t-test analysis with the assumption of equal variances after testing homogeneity of variance through Levene's test. Result shows that groups taught though explicit block modeling approach and conventional method differed significantly $(t=5.12, d f=46, p$ value $<0.001$ ) on mean gain scores (M-difference=6.53).

Table 3. Significance of Difference of Posttest Scores

\begin{tabular}{|c|c|c|c|c|c|c|c|}
\hline \multirow[b]{2}{*}{$\begin{array}{c}\text { Test } \\
\text { Compared }\end{array}$} & \multirow[b]{2}{*}{ Test used } & \multicolumn{2}{|c|}{ Mean Score } & \multicolumn{4}{|c|}{ t-test for comparison of means } \\
\hline & & Control & Experimental & $\begin{array}{c}\text { Mean } \\
\text { Difference }\end{array}$ & $\mathbf{t}$ & df & $\begin{array}{c}\text { p- } \\
\text { value }\end{array}$ \\
\hline Posttests & $\begin{array}{c}\text { Independent } \\
\text { Two-Sample t- } \\
\text { test }\end{array}$ & 8.37 & 14.90 & 6.53 & 5.12 & 46 & $<0.001$ \\
\hline
\end{tabular}

Note: Levene's Test Results: F-value=0.325, sig. value=0.565; equal variances assumed. Result is highly significant at $p<0.01$ )

\section{Discussion}

Cross-analysis revealed an increase in mean scores of both groups from pretest to posttest. Though both groups started at "Developing" level, the experimental group marks higher mean gain than control group (2pts. vs. 6pts.) which reflects Block modeling as a better problem-solving technique than the usual 4-step method. This is supported by Sonico (2012), Cheong (2002), Morin et al. (2017), Emeny (2014) and Sung (2017) showing that students acquired skills in visual approaches and contribute to a better understanding of abstract problems. Moreover, it facilitates spatial reasoning in students of all ages which is consistent to the study of Casey and Fell (2018) and Hong et al. (2009). Students should make use of study materials such as charts, maps and any other visual aid to address the needs of students in problem solving skills (Moussa, 2018).

Results showed that the improvement of students' problem-solving skill (M-increase=6.84) after explicit block modeling is highly significant $(\mathrm{t}=24.31, \mathrm{df}=23, \mathrm{p}$-value $<0.001)$. This implies that the model significantly maximized problem-solving skills, hence effective for text-based problem cognition and processing. Benefits of teaching this visual strategy where 4th and 8th grade students consistently come in first on international mathematics exams, students learn how to solve problems using the bar modeled strategy (Hoven \& Garelick, 2007). Fosnot \& Dolk also derived significant findings that supported his claim of visually modeled problem solving effectiveness (Fosnot \& Dolk, 2002). Furthermore, several studies have shown that Block Modeling is an effective tool in representing and visualizing relationships between patterns in number sense and developed mathematical problem solving skills (Kaur, 2019; Kroesbergen et al., 2004; Rozencwajg, 1991; Van Garderen, 2006). The said model also establishes creativity of students which helps them in critical reasoning (Casinillo et al., 2020b; Rashidov, 2020).

A further look at the descriptive statistics revealed that experimental group $(M=14.90)$ outperformed their counterparts in control group $(M=8.37)$ indicating that there is a significant development in students' skills both cognition and processing in worded problem-solving. This result is consistent to the existing studies in the literature (Amalia et al., 2017; Peranginangin \& Surya, 2017; Wahyuni et al., 2017). Kho, Yeo and Lim corroborate this finding as significant difference was also observed in their study about Singapore model method (Kho, Yeo \& Lim, 2009). Through the construction of a pictorial model, students gain better understanding of the problem and develop their abilities in 
mathematical thinking and problem solving (Hong et al., 2009). In visual instruction, teachers are able to engage different learning styles, and the visual nature builds a foundation for the student as they encounter increasingly difficult concepts and problems (Coyne, 2014). It is worth noting that improving a teaching strategy is vital in teaching and learning process (Casinillo \& Guarte, 2018).

\section{Conclusion}

This study concluded that Modeling blocks as a visual tool to mathematical problems effectively and potentially develops Grade 7 students' problem-solving skills and cognitive thinking. Hence, Modeling blocks develops the fundamental knowledge and understanding of students in worded problem solving and a nice aid in imparting concepts in mathematics. This affirms the Constructivism theory as students are able to construct meaning to a problem through block representations which reinforce visualization skills and facilitate processing information, making connections, and problem-solving capabilities. Furthermore, with this strategy, students show happiness and interest in learning mathematical problems. Hence, this study recommends that Explicit Block Modeling visualization tool should be incorporated in mathematics instruction in support to the realization of the goals of Philippine K-12 Mathematics Curriculum.

\section{References}

Amalia, E., Surya, E., \& Syahputra, E. (2017). The effectiveness of using problem based learning (PBL) in mathematics problem solving ability for junior high school students. International Journal of Advance Research and Innovative Ideas in Education, 3(2), 3402-3406. http://citeseerx.ist.psu.edu/viewdoc/download?doi=10.1.1.1039.1005\&rep=rep1\&type=pdf.

Casey, B. M., \& Fell, H. (2018). Spatial Reasoning: A Critical Problem-Solving Tool in Children's Mathematics Strategy Tool-Kit. Visualizing Mathematics, 47-75. https://doi.org/10.1007/978-3319-98767-5_3.

Casinillo, L., \& Aure, M. R. K. (2018). Econometric evidence on academic performance in basic calculus of science, technology, engineering and mathematics (STEM) senior high students. Journal of $\begin{array}{lll}\text { Educational and Human Resource Development, 6, 238-249. } & \text {. }\end{array}$ http://www.ijterm.org/index.php/jehrd/article/view/101.

Casinillo, L. F., \& Casinillo, E. L. (2020). Modelling Experiences and its Factors in General Mathematics: The Case of Grade 11 Students. Indonesian Journal of Educational Research and Review, 3(2), 25-34. http://dx.doi.org/10.23887/ijerr.v3i2.25670.

Casinillo, L. F., Galenzoga, R. S., \& Raagas, D. L. (2020). Evaluating mathematics learning experience of grade 7 students of Bato School of Fisheries. International Journal of and Teaching (IJIET), 4(2), 193-207. https://doi.org/10.24071/ijiet.v4i2.2513.

Casinillo, L. F., \& Guarte, J. M. (2018). Evaluating the effectiveness of teaching strategies: the case of a national vocational school in Hilongos, Leyte. Review of Socio-Economic Research and Development Studies, 2(1), 64-79. http://www.reserds.com/wp-content/uploads/2020/04/Vol-2-2018-pp.-6580-Paper-4.pdf.

Casinillo, L. F., Palen, M. A. E., Casinillo, E. L., \& Batidor, P. G. (2020b). Assessing Senior High Student's Learning Experiences in Mathematics. Indonesian Journal of Educational Studies, 23(1), 44-60. https://ojs.unm.ac.id/Insani/article/view/13437.

Cheong, Y. K. (2002). The Model Method in Singapore. The Mathematics Educator, 6(2), 47-64. http://citeseerx.ist.psu.edu/viewdoc/download?doi=10.1.1.555.5563\&rep=rep1\&type=pdf.

Coyne, C. (2014). Visual Approach to Math Instruction is Good Fit for All Learners. Marshall Cavendish Education.

Emeny, W. (2014). Bar modelling- a powerful visual approach for introducing number topics. Retrieved June 10, 2017 http://www.greatmathsteachingideas.com/2014/12/26/ barmodelling-a- powerful-visual-approach-for-introducing-number-topics/.

Fong, H. K. (1999a). Some generic principles for solving mathematical problems in the classroom. Teaching and Learning, 19(2), 80-83. http://hdl.handle.net/10497/383. 
Fong, H. K. (1999b). Top marks. Addison Wesley Longman.

Fong, H. K. (1993). Challenging mathematical problems for primary school: The model approach. Kingsford Educational Services.

Garderen, D., \& Montague, M. (2003). Visual-spatial representation, mathematical problem solving, and students of varying abilities. Learning Disabilities Research \& Practice, 18, 246-254.

Gonzales, P., Guzmán, J.C., Partelow, L., Pahlke, E., Jocelyn, L., Kastberg, D., and Williams, T. (2004). Highlights from the Trends in International Mathematics and Science Study (TIMSS) 2003 (NCES 2005-005). U.S. Department of Education. Washington, DC: National Center for Education Statistics. https://nces.ed.gov/timss/pdf/naep_timss_pisa_comp.pdf.

Hoven, J., \& Garelick, B. (2007). Singapore math: Simple or complex?. Educational Leadership, 65(3), 28. http://nychold.com/art-hoven-el-0711.pdf..

Kaur, B. (2019). The why, what and how of the 'Model'method: A tool for representing and visualising relationships when solving whole number arithmetic word problems. ZDM,51(1), 151-168. https://doi.org/10.1007/s11858-018-1000-y.

Kenan, K. X. F. (2018). Seeing and the ability to see: a framework for viewing geometric cube problems. International Electronic Journal of Mathematics Education,13(2), 57-60. https://doi.org/10.12973/iejme/2695.

Krawec, J. L. (2014). Problem representation and mathematical problem solving of students of varying math ability. Journal of Learning Disabilities, 47(2), 103-115. https://doi.org/10.1177\%2F0022219412436976.

Kroesbergen, E. H., Van Luit, J. E., \& Maas, C. J. (2004). Effectiveness of explicit and constructivist mathematics instruction for low-achieving students in the Netherlands. The Elementary School Journal, 104(3), 233-251. https://doi.org/10.1086/499751.

Kho, T. H. (1982). The use of models in the teaching of mathematics to primary school children. Teaching of mathematics. Singapore Association for the Advancement of Science \& Singapore Science Centre.

Leonard, J. (2018). Culturally specific pedagogy in the mathematics classroom: Strategies for teachers and students. Routledge.

Lowrie, T. (2020). The utility of diagrams in elementary problem solving. Cognitive Development, 55(1). https://doi.org/10.1016/j.cogdev.2020.100921.

Morin, L. L., Watson, S. M., Hester, P., \& Raver, S. (2017). The use of a bar model drawing to teach word problem solving to students with mathematics difficulties. Learning Disability Quarterly, 40(2), 91-104. https://doi.org/10.1177\%2F0731948717690116.

Moussa, N. (2018). Learning Styles and the Adoption of Modern Technology among Adult Learners.

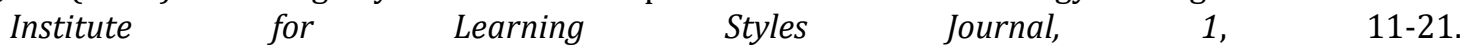
http://www.auburn.edu/academic/education/ilsrj/Journal\%20Volumes/Spring\%202018\%20Vo 1\%201\%20PDFs/LearningStyles\%20Moussa.pdf.

Ng, C. H., \& Lim, K. H. (2001). A handbook for mathematics teachers in primary schools. Federal Publications.

Peranginangin, S. A., \& Surya, E. (2017). An analysis of students' mathematics problem solving ability in VII grade at SMP Negeri 4 Pancurbatu. International Journal of Sciences: Basic and Applied $\begin{array}{ll}\text { Research } & \text { (IJSBAR), 33(2), }\end{array}$ http://gssrr.org/index.php?journal=JournalOfBasicAndApplied\&page=article\&op=view\&path\%5 $\mathrm{B} \% 5 \mathrm{D}=7330$.

Petti, W. (2014). Math Problem Solving with Pictures. Retrieved from http://www.education world.com/a_curr/ mathchat/mathchat022.shtml.

Rashidov, A. S. (2020). Development of creative and working with information competences of students in mathematics. European Journal of Research and Reflection in Educational Sciences, 8, 3. https://www.idpublications.org/wp-content/uploads/2020/03/Full-Paper-DEVELOPMENT-OF- 


\section{CREATIVE-AND-WORKING-WITH-INFORMATION-COMPETENCES-OF-STUDENTS-IN-} MATHEMATICS.pdf.

Rellensmann, J., Schukajlow, S., \& Leopold, C. (2017). Make a drawing. Effects of strategic knowledge, drawing accuracy, and type of drawing on students' mathematical modelling performance. Educational Studies in Mathematics, 95(1), 53-78. https: //doi.org/10.1007/s10649016-9736-1.

Rozencwajg, P. (1991). Analysis of problem solving strategies on the Kohs Block Design Test. European Journal of Psychology of Education, 6(1), 73-88. https://doi.org/10.1007/BF03173149.

Sonico, K. (2012). The Model Method in Solving Word Problems. DBaileyConnect.

Suarez, M. G. \& Casinillo, L. F. (2020). Effect of strategic intervention material (SIM) on academic performance: evidence from students of science VI. Review of Socio-Economic Research and Development Studies, 4(1), 20-32.

Sung, E. (2017). The influence of visualization tendency on problem-solving ability and learning achievement of primary school students in South Korea. Thinking skills and Creativity, 26, 168175. https://doi.org/10.1016/j.tsc.2017.10.007.

Van Garderen, D. (2006). Spatial visualization, visual imagery, and mathematical problem solving of students with varying abilities. Journal of learning disabilities,39(6), 496-506. https://doi.org/10.1177\%2F00222194060390060201.

Wahyuni, S., Indrawati, I., Sudarti, S., \& Suana, W. (2017). Developing science process skills and problem solving abilities based on outdoor learning in junior high school. Jurnal Pendidikan IPA Indonesia, 6(1), 23-31. https://doi.org/10.15294/jpii.v6i1.6849.

Yunzal, A. N. \& Casinillo, L. F. (2020). Effect of physics education technology (PhET) simulations: evidence from stem students' performance. Journal of Educational Research and Evaluation, 4(3), 221-226. http://dx.doi.org/10.23887/jere.v4i3.27450. 